\title{
Perceived Attitudes and Benefits Towards Teaching Evidence Based Practice among Physiotherapy Lecturers at Tertiary Institutions in South Africa
}

\begin{abstract}
:
Evidence-based practice $(E B P)$ is gaining momentum in the physiotherapy profession. The main focus of EBP, however, has been in clinical practice and in the move towards global EBP, very little attention has been given to the contents of physiotherapy education programs. There is very limited information regarding the attitudes of health professional lecturers, especially physiotherapists, towards the teaching of evidence based practice. The aim of this study was to determine the attitudes of lecturers and use of evidence in teaching among physiotherapists at tertiary institutions in

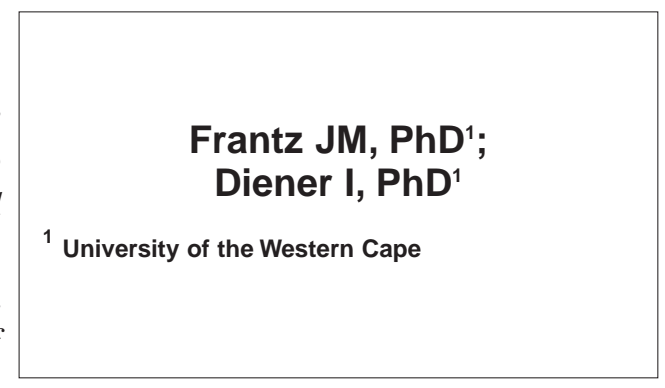
South Africa. The study employed a within stage mixed model approach. The study population consisted of all physiotherapy lecturers at the 8 training institutions in South Africa. Out of 76 physiotherapy lecturers at the 8 institutions, the response rate to the questionnaire was 47\% (35). Respondents identified that teaching EBP depends on personal experience, current literature, and availability of time, current practice patterns and CPD courses. Barriers to including evidence in the content of what is being taught were mainly time constraints, accessibility of journals, workload and knowledge on how to obtain the evidence. Facilitators to including evidence in subject content were adequate resources and a well equipped library, the environment and departmental support/encouragement. Teaching EBP requires the integration of factors such as research evidence, clinical expertise and patient values. Although the majority of respondents in the current study demonstrated a positive attitude towards teaching EBP, they reported finding it difficult to implement it in practice due to several identified barriers. It can only be to the benefit of lecturers, students and patients if university departments create favourable circumstances for lecturers to facilitate teaching of EBP.
\end{abstract}

KEYWORDS: EVIDENCE BASED TEACHING, PHY SIOTHERA PISTS, ATTITUDES.

\section{INTRODUCTION}

According to Sacket, Rossenberg, Gray, Haynes and Richardson (1996), evidencebased practice (EBP) has been defined as "integrating individual clinical expertise with the best available external clinical evidence from systematic research". The authors' further state that research evidence can be used for three purposes namely: (1) the selection of standardized assessment tools; (2) the interpretation of scores on assessment tools and (3) the selection of therapeutic, rehabilitative and promotive interventions. EBP is gaining momentum in the physiotherapy profession. However, Chipchase, Dalton, Williams and Scutter (2004) proposed that the main focus of EBP has been in clinical practice, with clinicians often receiving criticism concerning the lack of evidence supporting physiotherapy techniques and modalities. In the move towards global EBP, while very little attention has been given to the contents of physiotherapy education programs. "If universities and physiotherapy educators are put under the same evidencebased practice spotlight, how well do their educational programs and curricula rate?" (Chipchase et al, 2004, p 133)

The concept of EBP practice encourages health care professionals to provide effective health care. However, are our current teaching styles and content facilitated or influenced by evidence? Klem and Weiss (2005) emphasised that in order to implement the teaching of clinical evidence into our curriculum, acquisition of new skills are required. These skills include the ability to locate and critically evaluate clinically relevant literature. Research in health forms an important part in the training of health professionals and it is essential to stimulate critical thinking and reasoning skills among health professionals. Incorporating EBP into the curriculum remains a challenge though (Burns and Foley, 2005). Tanner (1999) stated that one of the broad aims of EBP is to decrease variations in the practices of clinicians thus eliminating worst practices and enhancing best practices. This is a challenge for both the lecturer and
Correspondence to:
Prof JM Frantz
Department of Physiotherapy
University of the Western Cape
Private Bag x17
Bellville 7530
Email: jfrantz@uwc.ac.za 
the student. With the inclusion of evidence into our teaching content, the traditional lecturing content must often be discarded and evidence for approaches taught must be drawn from published research (Rambur, 1999). Maintaining an evidence-based curriculum content requires dedication, knowledge and practice (Petrisor and Bhandari, 2006). These authors highlight that it is important to ensure that students understand that evidence-based teaching is aimed to enhance quality patient care.

In a survey of English physiotherapists, Metcalfe et al (2001) found that despite most therapists believing that research is important for professional practice, barriers to uptake and implementation of evidence included:

1. difficulties accessing research,

2. inadequate evaluative skills in assessing the quality of research findings,

3. insufficient time to devote to "research" activities and

4. the lack of relevance or applicability of the research findings to the clinical setting.

Although many health professions (including physiotherapy) have adopted the concept of EBP, it is not clear what the challenges are that educators face when attempting to teach EBP. There is very limited information regarding the attitudes of health professional lecturers, especially physiotherapists, towards the teaching of EBP. The aim of this study was to determine the attitudes of lecturers and use of evidence in teaching among physiotherapists at tertiary institutions in South Africa.

\section{METHOD}

The study population consisted of all physiotherapy lecturers at the 8 training institutions in South Africa. According to information obtained from the various institutions in 2007, there were 76 physiotherapy lecturers distributed amongst the 8 institutions. The study employed a within stage mixed model approach. The questionnaire used was based on literature and consisted of both closed and open-ended questions (Johnston, Leung, Fielding, Tin and Ho, 2003). The biodemographic data and attitudes and beliefs towards EBP teaching were collected with closed-ended questions. The openended questions aimed at identifying the barriers and facilitators towards evidence-based practice teaching. The questionnaire was piloted amongst parttime lecturers, who were not included in the main study. Questionnaires were distributed via e-mail to a list of email addresses of staff in the physiotherapy department of each university, which was obtained from the secretaries of departments. Responses were e-mailed back to one of the researchers (ID) who then forwarded the completed questionnaires anonymously to the other researcher (JF) who captured the data as accurately as possible. Data was captured on an Excel spreadsheet and later analysed using SPSS. The open-ended questions were analysed separately by both researchers and common themes were identified. Themes were compared and a consensus reached on those who best described the information presented.

\section{RESULTS}

The response rate to the questionnaire was $47 \%$ (35). Demographics of the respondents are reflected in Table $\mathbf{1}$. The information is presented according to each training institution. The most common areas being taught by the respondents are neurology (34\%) and orthopaedic manipulative therapy (23\%).

Table 1: Demographics of respondents $(\mathrm{N}=35)$

\begin{tabular}{|c|c|c|c|c|c|c|c|c|}
\hline & UWC & US & UCT & KZN & OFS & UP & WITS & UL \\
\hline Total no. of lecturers & 10 & 11 & 8 & 7 & 8 & 9 & 12 & 9 \\
\hline $\begin{array}{l}\text { GENDER } \\
\text { MALE } \\
\text { FEMALE }\end{array}$ & $\begin{array}{l}1 \\
6\end{array}$ & $\begin{array}{l}0 \\
6\end{array}$ & $\begin{array}{l}1 \\
3\end{array}$ & $\begin{array}{l}1 \\
2\end{array}$ & $\begin{array}{l}0 \\
2\end{array}$ & $\begin{array}{l}0 \\
3\end{array}$ & $\begin{array}{l}1 \\
7\end{array}$ & $\begin{array}{l}1 \\
1\end{array}$ \\
\hline $\begin{array}{l}\text { AGE } \\
31-40 \text { YRS } \\
41-50 \text { YRS } \\
51-60 \text { YRS } \\
>60 \text { YRS }\end{array}$ & $\begin{array}{l}3 \\
1 \\
3\end{array}$ & $\begin{array}{l}4 \\
1 \\
1\end{array}$ & $\begin{array}{l}2 \\
2\end{array}$ & $\begin{array}{l}1 \\
2\end{array}$ & $\begin{array}{l}1 \\
1\end{array}$ & $\begin{array}{l}1 \\
2\end{array}$ & $\begin{array}{l}6 \\
1 \\
1\end{array}$ & 2 \\
\hline $\begin{array}{l}\text { STATUS } \\
\text { LECTURER } \\
\text { SNR LECT } \\
\text { ASS PROF } \\
\text { PROFESSOR }\end{array}$ & $\begin{array}{l}2 \\
4 \\
1\end{array}$ & $\begin{array}{l}5 \\
1\end{array}$ & $\begin{array}{l}1 \\
1 \\
1 \\
1\end{array}$ & 3 & 2 & $\begin{array}{l}1 \\
2\end{array}$ & $\begin{array}{l}7 \\
1\end{array}$ & $\begin{array}{l}1 \\
1\end{array}$ \\
\hline $\begin{array}{l}\text { QUALIFICATIONS } \\
\text { DIPLOMA } \\
\text { BACHELORS DEGREE } \\
\text { MASTERS DEGREE } \\
\text { DOCTORAL DEGREE }\end{array}$ & $\begin{array}{l}4 \\
3\end{array}$ & 6 & $\begin{array}{l}2 \\
2\end{array}$ & $\begin{array}{l}1 \\
2\end{array}$ & $\begin{array}{l}1 \\
1\end{array}$ & $\begin{array}{l}1 \\
2\end{array}$ & $\begin{array}{l}7 \\
1\end{array}$ & $\begin{array}{l}1 \\
1\end{array}$ \\
\hline
\end{tabular}


This was followed by teaching in the area of community health (14\%), orthopaedics (9\%) and sports injuries (9\%). The other respondents taught in the areas of respiratory care and research methodology.

Three $(9 \%)$ of the respondents had a Bachelors degree and were teaching at undergraduate level. Twenty-three (66\%) lecturers had a Masters degree, and of these 10 were teaching at undergraduate level only, 1 at postgraduate level only and 12 at both undergraduate and postgraduate levels. The remaining $9(25 \%)$ respondents had doctoral degrees and they all taught at both undergraduate and postgraduate level. The common mode for number of years taught by the lecturers was between 1 and 5 years. Senior lecturers, associate professors and professors were found to have been lecturing for a common mode of $6-10$ years.

Table 2 below presents the responses to statements viz. attitudes towards and beliefs about including evidence in the content of teaching. From the responses, only $63 \%$ reported that they based their teaching on evidence and $20 \%$ agreed that including evidence into your teaching content contributes to an increased workload.
Table 3 highlights the response as it relates to lecturer status. Associations between various variables and the questions relating to evidence-based teaching was done and a significant association was found between age and the fact that keeping up with the evidence in their area tended to increase workload $(\mathrm{p}<0.05)$. Having a postgraduate degree was also significantly associated with being able to confidently perform a literature search and not finding EBP as an increase in workload $(p<0.05)$. The data of the open-ended questions is presented as various themes under each section.

\section{What do you see as evidence-based teaching?}

Evidence based teaching was defined in various ways with the most common being "teaching based on the best available evidence" (21). However, teaching based on the clinical experience of the lecturer was also highlighted by some of the respondents (5). Another reply to this question highlighted the idea that evidence based teaching also involves the students to evaluate the literature themselves and to take responsibility for their own learning.
When teaching, what factors influence your choice of assessment and outcome measures suggested to or required from students, and which sources of information do you use in this regard?

The most prevalent factors influencing assessment methods and outcome measures taught were classified as available literature (12) and availability of existing outcome measures (15). A quote highlighting this is: "The availability of the outcome measures and the userfriendliness of the measures and whether it is level and appropriate for students...". Another important factor to take into consideration is demonstrated by the following comment: "International research needs to be appreciated in a pragmatic way and clinically appropriate outcome measures for a South African context need to be selected".

Fifteen (15) responses mentioned the existing curriculum, handbooks and journal articles as the source for their choice of outcome measures. Five (5) made use of self-devised outcome measures and two (2) mentioned research in their departments on development and validation of questionnaires for the South African population.

Table 2: Responses per question ( $\mathrm{N}=35$ )

\begin{tabular}{|l|l|l|l|}
\hline Question & Agree & Unsure & Disagree \\
\hline Evidence based practice improves patient care & 28 & 7 & 0 \\
\hline Teaching should be based on the best available evidence & 34 & 1 & 0 \\
\hline I base my teaching on the best available evidence & 22 & 12 & 1 \\
\hline I would find it difficult to change what I currently teach. & 1 & 6 & 28 \\
\hline $\begin{array}{l}\text { We should change what we teach if good quality evidence } \\
\text { suggests we should }\end{array}$ & 34 & 1 & 0 \\
\hline $\begin{array}{l}\text { I would confidently be able to undertake a literature search } \\
\text { to support my teaching }\end{array}$ & 30 & 4 & 1 \\
\hline $\begin{array}{l}\text { Adoption of EBP teaching is another demand on already } \\
\text { overloaded lecturers }\end{array}$ & 7 & 5 & 23 \\
\hline $\begin{array}{l}\text { The practical demands of work make it impossible for me to keep } \\
\text { up-to-date with current evidence relating to my teaching }\end{array}$ & 9 & 10 & 16 \\
\hline $\begin{array}{l}\text { I am able to keep up to date with current practices to } \\
\text { inform my teaching? }\end{array}$ & 16 & 14 & 5 \\
\hline $\begin{array}{l}\text { I have no difficulties obtaining copies of published research } \\
\text { papers relating to my teaching }\end{array}$ & 24 & 3 & 8 \\
\hline $\begin{array}{l}\text { I would like to assess current best evidence more often } \\
\text { than I currently do }\end{array}$ & 34 & 0 & 1 \\
\hline
\end{tabular}


Table 3: Responses according to lecturer status $(\mathrm{N}=35)$

\begin{tabular}{|c|c|c|c|}
\hline STATUS & Question & +ve response & -ve response \\
\hline $\begin{array}{l}\text { Lecturer (22) } \\
\text { Senior Lecturer (9) } \\
\text { Associate Prof/Prof (4) }\end{array}$ & 1 & $\begin{array}{l}15 \\
9 \\
3\end{array}$ & $\begin{array}{l}7 \\
0 \\
1\end{array}$ \\
\hline $\begin{array}{l}\text { Lecturer (22) } \\
\text { Senior Lecturer (9) } \\
\text { Associate Prof/Prof (4) }\end{array}$ & 2 & $\begin{array}{l}21 \\
9 \\
4\end{array}$ & $\begin{array}{l}1 \\
0 \\
0\end{array}$ \\
\hline $\begin{array}{l}\text { Lecturer (22) } \\
\text { Senior Lecturer (9) } \\
\text { Associate Prof/Prof (4) }\end{array}$ & 3 & $\begin{array}{l}14 \\
6 \\
2\end{array}$ & $\begin{array}{l}8 \\
3 \\
2\end{array}$ \\
\hline $\begin{array}{l}\text { Lecturer (22) } \\
\text { Senior Lecturer (9) } \\
\text { Associate Prof/Prof (4) }\end{array}$ & 4 & $\begin{array}{l}16 \\
8 \\
4\end{array}$ & $\begin{array}{l}6 \\
1 \\
0\end{array}$ \\
\hline $\begin{array}{l}\text { Lecturer (22) } \\
\text { Senior Lecturer (9) } \\
\text { Associate Prof/Prof (4) }\end{array}$ & 5 & $\begin{array}{l}18 \\
9 \\
4\end{array}$ & $\begin{array}{l}4 \\
0 \\
0\end{array}$ \\
\hline $\begin{array}{l}\text { Lecturer (22) } \\
\text { Senior Lecturer (9) } \\
\text { Associate Prof/Prof (4) }\end{array}$ & 6 & $\begin{array}{l}18 \\
8 \\
4\end{array}$ & $\begin{array}{l}4 \\
1 \\
0\end{array}$ \\
\hline $\begin{array}{l}\text { Lecturer (22) } \\
\text { Senior Lecturer (9) } \\
\text { Associate Prof/Prof (4) }\end{array}$ & 7 & $\begin{array}{l}12 \\
8 \\
3\end{array}$ & $\begin{array}{l}10 \\
1 \\
1\end{array}$ \\
\hline $\begin{array}{l}\text { Lecturer (22) } \\
\text { Senior Lecturer (9) } \\
\text { Associate Prof/Prof (4) }\end{array}$ & 8 & $\begin{array}{l}8 \\
5 \\
3\end{array}$ & $\begin{array}{l}14 \\
4 \\
1\end{array}$ \\
\hline $\begin{array}{l}\text { Lecturer (22) } \\
\text { Senior Lecturer (9) } \\
\text { Associate Prof/Prof (4) }\end{array}$ & 9 & $\begin{array}{l}10 \\
5 \\
2\end{array}$ & $\begin{array}{l}12 \\
4 \\
2\end{array}$ \\
\hline $\begin{array}{l}\text { Lecturer (22) } \\
\text { Senior Lecturer (9) } \\
\text { Associate Prof/Prof (4) }\end{array}$ & 10 & $\begin{array}{l}13 \\
7 \\
4\end{array}$ & $\begin{array}{l}9 \\
2 \\
0\end{array}$ \\
\hline $\begin{array}{l}\text { Lecturer (22) } \\
\text { Senior Lecturer (9) } \\
\text { Associate Prof/Prof (4) }\end{array}$ & 11 & $\begin{array}{l}22 \\
9 \\
4\end{array}$ & $\begin{array}{l}0 \\
0 \\
0\end{array}$ \\
\hline
\end{tabular}

What factors influence/inform your choice of intervention that you teach, and what sources of information do you use in this regard?

Respondents identified factors influencing treatment methods taught and these were categorized into 4 main themes viz. personal experience (15); current literature (22); availability of time (14); current practice and CPD courses (12). A quote summarizing some of the responses was: “.... clinical relevance, personal experience with the intervention, support from literature and the availability of time for preparation for teaching."

Most lecturers (24) indicated using journal articles as a source of information to their choice of interventions in their field of teaching. Twenty-two (22) lecturers marked the existing curriculum and twelve (12) marked available handbooks as a source of information. CPD courses (16), clinical experts in the field (13) and self-devised treatment approaches (12) also informed teaching of intervention strategies.

What barriers would you identify to evidence based teaching at a tertiary institution?

Barriers to including evidence in the content of what is being taught was categorized into 4 main themes viz. time (15), accessibility of journals (11); workload (9); knowledge on how to obtain the evidence (5). A quote that incorporates most of the barriers and is similar to many others was:

"Lack of access to journals in the library, lack of equipment, lack of support from the institution, too much clinical supervision and also not knowing how to find evidence are major barriers."

Another barrier that surfaced in four (4) comments with the same theme was:

"It is often difficult for students to understand an evidence-based approach to teaching and they often give feedback from physiotherapists in the clinical field who may expect them to have learned a certain technique/modality in a particular manner. Unfortunately the students then believe that their course 
is not covering all the topics it should and believe we as lecturers are doing a poor job."

Three lecturers also mentioned that the students' need a mind shift as to do their own research into the evidence for some interventions instead of expecting the lecturer to "give it all to them" in a lecture.

\section{What are the facilitators to evidence based teaching?}

Facilitators to including evidence in the content of what we are teaching was categorized into three main themes viz. adequate resources and a well equipped library (14), the environment (10) and support/encouragement (9). This is supported by the following quote:

“...good working environment, availability of electronic journals, a vibrant journal club in the department with support from colleagues..."

Another comment summarized the view of three other lecturers (3) about the importance of exposure of students:

"I think the biggest (facilitator) is getting greater exposure and acceptance at a clinical level in all areas of health care and that the students are being exposed to the challenges of providing evidence for practice at all levels of care from consultants on ward rounds to the students themselves".

\section{DISCUSSION}

The question that was being addressed by this study was whether physiotherapy educators were basing their curriculum content on evidence? Respondents to this study included a range of educators ranging from lecturers to professors teaching in various areas of physiotherapy at both undergraduate and postgraduate level. This would be an indication that if EBP teaching occurred, it would be at all levels of training as advocated by Collins, Leffingwell and Belar (2007).

Evidence based practice (EBP) is a meaningful process that the physiotherapy profession has embraced and thus the challenge of teaching EBP. Wood (2008) highlighted that although EBP has been advocated for undergraduate and postgraduate teaching and defined as the gold standard of practice there are still some confusing messages in literature. According to Collins et al (2007), teaching EBP requires the integration of factors such as research evidence, clinical expertise and patient values. The authors further state that the integration of these factors should be throughout the training period of the student. However, to achieve these goals lecturers are faced with real challenges.

\section{Attitudes towards and beliefs about teaching of EBP}

The majority of lecturers expressed the desire to follow an EBT approach. They agreed that EBP improves patient care, and that teaching should follow an EBT approach and that lecturers should keep up with the current available evidence for best practice (Table 3). It is of concern, however, that $20 \%$ of lecturers are still unsure whether EBP will improve patient care and that $37 \%$ of lecturers do not base their teaching on the best available evidence. According to Jette et al (2003), physiotherapists value the principles of EBP, however, they report finding it difficult to implement it in practice. This might highlight the need to provide therapists and lecturers with assistance to incorporate research into practice. In a recent study by Bridges, Bierema and Valentine (2007), the authors concluded that multiple practice change strategies will be needed to facilitate change in practice. The study provides evidence that fostering selfdirected learning by using the natural teaching method of reflecting on the problems at the point of care facilitated the adoption of EBP. This finding is consistent with previous research by Warren and Pierson (1994) who found that physical therapy students with a master's degree demonstrated a more positive attitude towards research than students with a baccalaureate degree.

\section{Barriers to the teaching of EBP}

Barriers identified by the respondents are real and is supported by other researchers (Brown, 1995; Kajermo, Nordstrom, Krusebrandt and Bjorvell, 2000). Many of the respondents highlighted that the teaching of EBP is dependent on whether information available is specific to the South African context. Technology was also highlighted as a much needed influence in the teaching of EBP. Schmidt and Brown (2007) suggested that we need to be innovative and creative when doing evidence-based teaching and use a framework that will address some of the barriers. Salbach et al (2007) did a cross-sectional mail survey to identify practitioner barriers (education, attitudes and beliefs, interest and perceived role, and selfefficacy) and organizational barriers (perceived support and resources) to physical therapists' implementation of EBP for people with stroke. The results demonstrated very similar barriers as identified in the current study. The most obvious barriers were a lack of training in the foundations of EBP in their academic preparation; and minimal training in searching or appraising research literature. Although $78 \%$ agreed that research findings are useful, 55\% agreed that a divide exists between research and practice. Like in the current study, almost all respondents were interested in learning EBP skills, but the average self-efficacy ratings were between $50 \%$ and $80 \%$ for searching and appraising the literature and below 50\% for critically appraising psychometric properties and understanding statistical analyses. Despite Internet access at work for $80 \%$ of respondents, only $8 \%$ were given protected work time to search and appraise the literature (Salbach et al 2007). This is also of concern in the current study's population group. Although $97 \%$ of the respondents expressed the desire to access current best evidence more often than they currently do, more than half of the group complained that they are overloaded and not able to keep up to date due to their work demands.

Utility and applicability of outcome measurement tools could also be a barrier to EBP and the teaching if it. This concern was expressed in one of the respondent's remarks: "International research needs to be appreciated in a pragmatic way and clinically appropriate outcome measures for a South African context need to be selected". This concern is emphasized by Bialocerkowski, Grimmer, Milanese and Kumar (2004) in their conclusion of a literature review that clinicians and 
researchers should be involved in producing research that is applicable to clinical practice, otherwise barriers will continue to be experienced when attempting to apply EBP to real life situations.

\section{Facilitators to teaching of EBP}

The majority of respondents in this study felt that access to data bases and a supportive working environment would allow them to improve their teaching of EBP. One of the comments, however, stressed that changing the students' attitude towards EBP is also important. The small amount of relevant current research available from medical education literature combined with our historically based traditions in physiotherapy education both suggest that patient encounters in the clinical setting are an essential component for graduating competent, effective physiotherapists (Chipchase et al, 2004). When being exposed to the challenges of providing evidence for practice, e.g. during discussions with other health practitioners, students could be made more aware of the need of EBP. Chipchase et al (2004) are of the opinion that the unfolding of EBP in the clinical arena in the last decade is probably another reason why academics are apprehensive of the same philosophy being applied to teaching and research. However, EBP is not only the existence of randomised controlled trials to support the use of a particular intervention. In reality, EBP includes three equally important factors (Sackett, Straus, Richardson, Rosenberg, Haynes, 2000): (1) The ability of a lecturer to decide on a treatment strategy which is supported by the best research evidence available but (2) interpreted in the light of the needs, values, and presenting condition of the current patient and (3) the lecturer's past clinical experience with similar patients.

\section{Is the teaching of evidence based prac- tice worth the effort?}

In most studies on qualified physiotherapists a change in attitude seemed to be hard. Flores-Mateo and Argimon (2007) reported after a systematic review of studies assessing the effectiveness of EBP teaching to improve knowledge, skills, attitudes and behavior of postgraduate healthcare workers, that small improvements in knowledge, skills, attitudes or behavior were noted when measured alone, but that a large improvement in skills and knowledge in EBP was noted when measured together in a total test score. Stevenson, Lewis and Hay (2004) investigated physiotherapists' attitudes towards EBP and change in their attitudes following an education package. In this study, physiotherapists also appeared to be in favour of the idea of EBP, but remained reluctant to change their practice. The process of changing attitudes in the clinical environment is a complex issue worthy of further research.

\section{The best way forward}

Reviewing outcome studies on the effect of EBP training in qualified practitioners and lecturers indicate that it is of utmost importance to foster a lifelong attitude of seeking the best available evidence for practice while students are training. This could be done in various ways. Lecturers and students can practise EBP in one of three modes - as a doer, a user, or a replicator. Physiotherapists learn from their work with patients, on teams with other health care professionals, and in dialogue with their colleagues (Fox and Bennett, 1998). A teaching institute has the potential to provide opportunities such as critical debate on research evidence within the teaching environment that may facilitate the propensity to adopt evidence based practice (Watkins and Marsick, 1996). The educators' role in moving evidence based practice forward is vital. Educators must not only follow the best available evidence for the assessment and intervention approaches they teach, but must also find the best way to teach these. Straus et al (2004) suggested that the various methods of teaching EBP must address the needs of different learners. Careful identification of learners' learning styles is important. Stevenson, Lewis and Hay (2004) concluded that physiotherapists seemed to be in favour of the idea of EBP, yet remained reluctant to change practice, because the process of changing attitudes in the clinical environment is a complex issue. McCluskey and Lovarini (2005) found that EBP skills and knowledge improved markedly with a targeted education intervention and outreach support. However, they also found that changes in behaviour were small. It may also take much effort to change behaviour of current lecturers, but if the approach can be established in undergraduate students, changing attitudes may be an easier process in clinicians and lecturers.

Educators should also assist in developing clinical guidelines and regularly evaluate these guidelines as well as implementing appropriate changes as new information surfaces. Flores-Mateo and Argimon (2007) emphasized that greater collaboration with organizations and individuals interested in preserving standards in academic medicine is required and this is equally important in physiotherapy. In addition, programmes that train health-care professionals have the responsibility for education and research. These programmes must stimulate interest in EBP education and should also be evaluated for their outcomes. Educators are in the position to create an evidence base by conducting valid, high quality research which has practical relevance (Davies, 1999).

Although barriers do exist for teaching of EBP, we as physiotherapy educators are encouraged to be proactive in improving practice by improving teaching and encouraging teaching based on current, relevant evidence. A model proposed by Oermann (2007) suggests that an evidence based approach to teaching should be done in 3 phases:

1. Asking questions about educational practices i.e. how and what we teach, and its relevance

2. Searching for, critically appraising and synthesizing available evidence

3. Determining its relevance for your own teaching, students and setting.

\section{CONCLUSION}

Although the majority of respondents in the current study demonstrated a positive attitude towards teaching EBP, there were several barriers to this approach identified. It can only be to the benefit of lecturers, students and patients if university departments create favourable circumstances for lecturers to facilitate teaching of EBP. 


\section{REFERENCES:}

Bialocerkowski A, Grimmer K, Milanese S, Kumar V (2004). Application of current research evidence to clinical physiotherapy practice. Journal of Allied Health 33 (4): 230-237.

Bridges P, Bierema L, Valentine T (2007). The propensity to adopt evidence-based practice among physical therapists. BMC Health Services Research 7: 103

Brown G (1995). Understanding barriers to basing nursing practice upon research: A communication model approach. Journal of Advanced Nursing 21: 154-157.

Chipchase L, Dalton M, Williams M, Scutter $\mathrm{S}$ (2004). Is education immune from evidencebased scrutiny? Australian Journal of Physiotherapy Editorial 50:133

Collins F, Leffingwell T, Belar C (2007). Teaching evidence based practice: implications for psychology. Journal of Clinical Psychology. 63(7): 657-670.

Flores-Mateo G, Argimon JM (2007). Evidence Based Practice Education in Postgraduate Health Care: A Systematic Review. BMC Health Services Research 7:119

Fox R, Bennett N (1998). Learning and change: Implications for continuing medical education. British Medical Journal. 316: 466-468.

Jette DU, Bacon K, Batty C, Carlson M, Ferland A, Hemingway R, Hill J, Ogilvie L, Volk D (2003). Evidence based practice: beliefs, attitudes, knowledge, and behaviors of physical therapists. Physical Therapy. 83:786-805.

Johnston J, Leung G, Fielding R, Tin K, Ho L (2003). The development and validation of a knowledge, attitude and behaviour questionnaire to assess undergraduate evidence-based practice teaching and learning. Medical Education, 37: 992-1000.

Kajermo K, Nordstrom G, Krusebrandt A, Bjorvell H (2000). Perceptions of research utilisation: Comparisons between health care professionals, nursing students and a reference group of nurse clinicians. Journal of Advanced Nursing. 31: 99-109.

Klem M, Weiss P (2005). Evidence based resources and the role of the librarians in developing evidence-based practice curricula. Journal of Professional Nursing. 21(6): 380-387.
McCluskey A, Lovarini M (2005). Providing education on evidence-based practice improved knowledge but did not change behavior: a before and after study. BMC Medical Education 5:40

Metcalfe C, Lewin R, Wisher S, Perry S, Banningan K, Moffett J (2001). Barriers to implementing the evidence base in four NHS therapies: dieticians, occupational therapists, physiotherapists nad speech and language therapists. Physiotherapy. 87:431-433.

O'Donnell C (2004). Attitudes and knowledge of primary care professionals towards evidence based practice: a postal survey. Journal of Evaluation in Clinical Practice. 10(2): 197-205

Oermann M (2007). Approaches to gathering evidence for educational practices in nursing. The Journal of Continuing Education in Nursing. 38(6): 250-255.

Petrisor B, Bhandari M (2006). Principles of teaching evidence based medicine. Injury: International Journal of the Care of the Injured. 37: 335-339.

Rambur B (1999). Fostering evidence-based practice in nursing education. Journal of Professional Nursing. 15: 270-274.

Sacket D, Rossenberg W, Gray J, Haynes R, Richardson W (1996). Evidence based medicine: what it is and what it isn't. British Medical Journal 312: 71-72.

Sacket D, Strauss S, Richardson W, Rosenberg W \& Haynes R (2000). Evidence based medicine: How to practice and teach EBM. Edinburgh; Churchill Livingstone.

Salbach NM, Jaglal SB, Korner-Bitensky N, Rappolt S and Davis D (2007). Practitioner and Organizational Barriers to Evidencebased Practice of Physical Therapists for People with Stroke. Physical Therapy 87: 10

Schmidt N and Brown J (2007). Use of the innovation-decision process teaching strategy to promote evidence based practice. Journal of Professional Nursing 23(3): 150-156.

Stevenson K, Lewis M, Hay E (2004). Do physiotherapists' attitudes towards evidencebased practice change as a result of an evidence-based educational programme? Journal of Evaluation and Clinical Practice 10(2): 207-17.
Straus SE, Green ML, Bell DS, Badgett R, Davis D, Gerrity M, Ortiz E, Shaneyfelt TM, Whelan C and Mangrulkar R (2004). Evaluating the teaching of evidence based medicine: conceptual framework. British Medical Journal 329;1029-1032

Tanner C (1999). Evidence based practice: Research and critical thinking. Journal of Nursing Education. 38: 99

Warren S and Pierson F (1994). Comparison of characteristics and attitudes of entry level bachelor's and master's degree students in physical therapy. Physical Therapy 74: 333348

Watkins K, Marsick V (1996). In action: Creating the learning organization. Alexandria, VA: American Society for Training and Development: 1996.

Wood M (2008). The State of Evidence-Based Practice. Clinical Nursing Research 17(2): 71-73 